\title{
Plant herbivore interactions: combined effect of ground water level, root vole grazing and sedge silication
}

\author{
Zbigniew Borowski ${ }^{1}$, Karol Zub ${ }^{2}$, Marcin Sulwinski ${ }^{3}$, Małgorzata Suska-Malawska ${ }^{3}$, and \\ Marek Konarazewski ${ }^{4}$ \\ ${ }^{1}$ Forest Research Institute \\ ${ }^{2}$ Mammal Research Institute \\ ${ }^{3}$ Warsaw University Faculty of Biology \\ ${ }^{4}$ University in Białystok
}

August 12, 2021

\begin{abstract}
1. Silicon mediated plant-herbivore interactions have gained increasing recognition and have now been studied in a wide range of species. Many studies have also considered accumulation of Si by plants as a process largely driven by geo-hydrological cycles. 2. To identify factors driving the water - plant $\mathrm{Si}$ - herbivore nexus we analysed the concentration of Si in fibrous tussock sedge (Carex appropinquata), the population density of the root vole (Microtus oeconomus) and the ground water level, over 11 years. 3. The largest influence of autumn Si concentration in leaves (Sileaf) was the level of the current year's ground water table, which accounted for $13.3 \%$ of its variance. The previous year's vole population density was weakly positively correlated with Sileaf and alone explained $9.5 \%$ of its variance. 4 . The only variable found to have a positive, significant effect on autumn Si concentration in rhizomes (Sirhiz) was the current year spring water level explaining as much as $60.9 \%$ of its variance. 5 . We conclude that the changes in Si concentration in fibrous tussock sedge are predominantly driven by hydrology, with vole population dynamics being secondary. Our results provide only partial support for the existence of plant-herbivore interactions, as we did not detect the significant effects of Si tussock concentration on the vole density dynamics. This was mainly due to low level of silification of sedges, which was insufficient to impinge herbivores. Future studies on plant-herbivore interactions should therefore mainly focus on identification of mechanisms and conditions allowing plants to accumulate silica at the levels sufficient to act as an anti-herbivore protection.
\end{abstract}

Title: Plant herbivore interactions: combined effect of ground water level, root vole grazing and sedge silication

Zbigniew Borowski ${ }^{\mathrm{a},{ }^{*}}$, Karol Zub ${ }^{\mathrm{b}}$, Marcin Sulwiński ${ }^{\mathrm{c}}$, Małgorzata Suska-Malawska ${ }^{\mathrm{c}}$ and Marek Konarzewski $^{\mathrm{d}}$

${ }^{a}$ Department of Forest Ecology, Forest Research Institute, Raszyn, Poland

${ }^{b}$ Mammal Research Institute Polish Academy of Sciences, Białowieża, Poland

${ }^{\mathrm{c}}$ Faculty of Biology, Biological and Chemical Research Centre, Warsaw University, Warsaw, Poland

${ }^{\mathrm{d}}$ Institute of Biology, University in Białystok, Białystok, Poland

*Corresponding Author: Zbigniew Borowski (z.borowski@ibles.waw.pl)

\section{Abstract}


1. Silicon mediated plant-herbivore interactions have gained increasing recognition and have now been studied in a wide range of species. Many studies have also considered accumulation of Si by plants as a process largely driven by geo-hydrological cycles.

2. To identify factors driving the water - plant $\mathrm{Si}$ - herbivore nexus we analysed the concentration of $\mathrm{Si}$ in fibrous tussock sedge (Carex appropinquata), the population density of the root vole (Microtus oeconomus ) and the ground water level, over 11 years.

3. The largest influence of autumn Si concentration in leaves ( $\mathrm{Si}_{\text {leaf }}$ ) was the level of the current year's ground water table, which accounted for $13.3 \%$ of its variance. The previous year's vole population density was weakly positively correlated with $\mathrm{Si}_{\text {leaf }}$ and alone explained $9.5 \%$ of its variance.

4. The only variable found to have a positive, significant effect on autumn Si concentration in rhizomes $\left(\mathrm{Si}_{\mathrm{rhiz}}\right)$ was the current year spring water level explaining as much as $60.9 \%$ of its variance.

5. We conclude that the changes in Si concentration in fibrous tussock sedge are predominantly driven by hydrology, with vole population dynamics being secondary. Our results provide only partial support for the existence of plant-herbivore interactions, as we did not detect the significant effects of Si tussock concentration on the vole density dynamics. This was mainly due to low level of silification of sedges, which was insufficient to impinge herbivores. Future studies on plant-herbivore interactions should therefore mainly focus on identification of mechanisms and conditions allowing plants to accumulate silica at the levels sufficient to act as an anti-herbivore protection.

Key-words : ground water level, plant defense, population density, tussock sedges, voles

\section{INTRODUCTION}

Recent studies suggest that the dynamics of the small mammal population are shaped primarily by the external factors (so-called: trophic interactions) such as predation and availability or quality of food (Klemola, et al. 2000; Lambin, et al., 2000; Oli, 2019, but see Adreassen et al., 2013). Among factors related to food quality, root and leaf silication induced by past overgrazing has recently received particular attention. A number of studies demonstrated that abrasive properties of silicon contained in the plant tissues deteriorate herbivore teeth (Calandra et al., 2016), cause abrasion of intestinal villi (Wieczorek et al. 2015b) as well as a reduction in body mass and survival prospects (Zub et al., 2014; Wieczorek et al., 2015a). Furthermore, plant responses to herbivory pressure has been observed within laboratory based studies, in which pressure from field voles (Microtus agrestis ) increased the presence of silicon in grass tissues by $400 \%$ (Massey \& Hartley, 2006).

Yet, the results of the field studies on the associations between induced silicon plant defence and mammalian herbivory have not been as clear as the laboratory ones. Studies conducted in Norway have shown that the induced grass response to the herbivory manifested by an increase in the content of silicon in plant tissues is extremely variable and depends, not only on the pressure of herbivorous mammals (rodents and reindeer), but also on the location, plant species and its genotype (Soninen et al., 2012). Quigley et al. (2020) demonstrated that $\mathrm{Si}$ concentration in grass leaves did not respond to large mammalian grazer exclusion studied in a climatic gradient, but was strongly affected by nutrient availability. In turn, field experiments carried out in Kielder Forest (UK) showed that after several months of density manipulation the level of silicon in wavy hair grass (Deschampsia caespitosa) leaves decreased by $22 \%$ on sites where field vole density had been reduced, but the increase in silicon content did not affect body weight of voles, nor their spring population growth rate or survival, which suggests that plant quality hypothesis is unlikely to explain the observed cyclicity in the Kielder Forest field vole population (Ruffino et al., 2018). Likewise, (Wieczorek et al., 2015a; but see Soninen et al., 2017) showed that vole herbivory elevated silicon levels in sedges, albeit with no detectable effect on the winter survival rates of voles.

The above inconsistencies may simply stem from the lack of sufficient statistical power of these analyses, since the longest of them lasted between three (Soninen et al., 2012) to four years (Wieczorek et al., 2015a) and are therefore based on a small number of degrees of freedom. Long-term studies, able to capture the time-course of the putative plant-herbivore association, are particularly needed because changes in silicon levels in plant tissues are not only due to grazing, but are also responsive to abiotic factors, chiefly water 
availability, which drives silicon absorption in form of silicic acid (Raven, 1983; Sangster, Hodson, \& Tubb, 2001; Kindomihou, Sinsin \& Meerts, 2006; Faisal et al., 2012; Brightly et al,, 2020). The effect of the water on the induction of silicon in sedge leaves has been indirectly demonstrated in European (Wieczorek et al., 2015a) and in African ecosystems (Quigley \& Anderson, 2014).

To address such short-term limitations in previous research, we analysed an 11-year time series of: ground water level; population dynamics of the root vole (Microtus oeconomus ); and silicon levels in the tissues of the fibrous tussock sedges (Carex appropinquata, Schumacher, 1801) - the main food source of the voles. To our knowledge, this is the longest time series ever used to test the effect of plant defences and water availability in plant-herbivore interactions. We tested whether: sedges induce silicon defences in response to the grazing by root voles; the feedback of silicon in sedges influence vole population dynamics; and whether ground water level influenced the plant-herbivore system. Following Wieczorek et al., (2015a) we did so by taking into consideration $\mathrm{Si}$ concentration in rhizomes $\left(\mathrm{Si}_{\text {rhiz }}\right)$ as well as in leaves $\left(\mathrm{Si}_{\text {leaf }}\right)$, as the dynamics of the plant-herbivore interaction can be different depending on the part of the plant. We predicted that $\mathrm{Si}_{\text {leaf }}$ should be positively affected by the previous year's vole population density. However, $\mathrm{Si}_{\mathrm{rhiz}}$ should be primarily stimulated by the same year herbivore-incurred damage. As Si uptake by sedges is positively driven by water availability, we also surmised that $\mathrm{Si}_{\text {leaf }}$ and $\mathrm{Si}_{\text {rhiz }}$ were likely to be positively affected by the level of ground water table in previous and/or current spring. Conversely, year-to-year changes of vole population density should be inversely correlated with the $\mathrm{Si}_{\text {leaf }}$ and $\mathrm{Si}_{\text {rhiz }}$ with a one-year time lag.

\section{STUDY AREA}

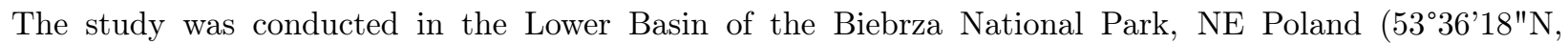
$\left.22 \mathrm{deg} 55^{\prime} 36^{\prime \prime} \mathrm{E}\right)$. The study area is located in a homogenous sedge wetland with vegetation dominated by plants from Cyperaceae family. The main plant species in the Park is the fibrous tussock sedge, which covers $85 \%$ of the area and forms hummock-hollow structures (Matuszkiewicz, 2020). The wetland has a seasonal water regime with the highest level during spring, when flooding is frequent. The climate is characterized by long winters ( $>100$ days), short and early springs, and short summers (77-85 days).

The main herbivores in the area are rodents and moose (Alces alces ). Root voles are the dominant rodent species in this habitat, making up $90 \%$ of small mammal communities (Borowski, 2002; 2011). We worked with a natural population of root voles which displays cyclical dynamics (Borowski, 2011). The study began in 2007, during which time various vole population peaks (2008-2009, 2015-2016) and crashes $(2007,2017)$ occurred (Fig. 1).

\subsection{VOLE DENSITIES}

In order to estimate vole population sizes we carried out Capture-Mark-Recapture (CMR) trapping freeliving populations in two sites, each 0,6 ha large and separated by $3 \mathrm{~km}$. The first site, called Gugny was trapped between 2007 and 2019, while the second, called Barwik, was trapped for 2012 to 2019. Trapping occurred at each site once a year in autumn (November).

Vole population size estimates were converted to density per ha based on a CMR method (see Borowski, 2011 for details).

\subsection{SEDGE SAMPLING}

Sedges are the main food of root voles, both in summer and winter. In summer, the diet is dominated by green parts of the plant, though in late autumn and winter voles also eat the woody parts, such as dry rhizomes and roots (Tast, 1966; Gębczyńska, 1970; Batzli \& Henttonen, 1990).

In the Barwik and Gugny sites, every November from 2014 to 2019, we collected 10 haphazardly selected samples of sedge tussocks at each site. This resulted in 120 Carex tussocks samples (10 per year in each site over 6 years). To determine for Si content, from each tussock we took biomass sample composed of leaves or rhizomes produced in the present year, physically connected with the tussocks (representing a single plant). Dead parts of the plant or decaying litter were discarded. As voles do not feed on decaying litter, we selected 
only leaves and rhizomes which were both physically connected and also composed of dried, non-decomposing tissues. We separated leaves from rhizomes, and samples were cleaned under running water, dried at $80{ }^{\circ} \mathrm{C}$ to a constant mass and stored in separate plastic bags for further analysis.

Data on Si concentrations in leaves and rhizomes from Gugny site (from 2007-2011) were collected in a similar manner as described above, for details see Wieczorek et al., (2015a). We calculated mean value of $\mathrm{Si}$ concentration in leaves or rhizomes from 10 samples collected for each year and site, thus our sample size was $\mathrm{N}=17$ (5 samples for period 2007-2011 from Gugny and 12 samples for period 2014-2019 from Gugny and Barwik).

\subsection{WATER LEVEL}

We measured water level using piezometers, with the instruments in both study sites, each located ca. 5 $\mathrm{km}$ from the Biebrza River. Five to six measurements of water level (m) were taken in May and June using the same respective piezometer. These measurements were then averaged to be used later used in analysis. The river and its floodplain form an interconnected spatially distributed system (Fisher et al.,1998) which experiences regular flooding, which occurs in spring.

\subsection{CHEMICAL ANALYSIS}

The above ground biomass and roots were separated and milled using a Tecator Cyclotec1093 mill. Each 150 mg sample of biomass was then digested in a 9:1 mixture of concentrated $\mathrm{HNO}_{3}$ and $\mathrm{HF}$ in Speedwave Four apparatus (Berghof, Germany), with temperatures reaching a maximum of $230{ }^{\circ} \mathrm{C}$. Si content in digested material was measured using atomic an absorption spectrometer, Contraa700 (Analytik Jena, Germany), in nitrous oxide-acetylene flame with $251.6 \mathrm{~nm}$ wavelength. Recovery of Si was determined using NCS DC 73349 certified material (recovery was within $91 \%$ to $102 \%$ with a mean of $96 \%$ ).

\subsection{STATISTICAL ANALYSES}

To analyse the data we used Generalized Linear Mixed Models (GLMM) withlog link function. We logtransformed all, but one (water level), variables to correct for their right skewed distribution. Model assumptions were checked using residual plots. These confirmed: $\varepsilon$ was normally distributed, model fits lacked heteroscedasticity, and no observations were disproportionately influential in any of the models.

To identify factors affecting the November $\mathrm{Si}$ concentrations in leaves or rhizomes we used the following variables, with their respective interactions, as the fixed terms: the autumn density of voles in the previous $(t-1)$ and the current $(t)$ year, the spring water level from the present (year $t$ ), and Si concentration in leaves or rhizomes in the present year (year $t$ ). In the final models only the significant interaction terms were retained. The study site (Gugny or Barwik) and year of study were used as a random factors. As the "study site" random factor has only two levels in some models it caused singularity and then was removed. We used year as a random factor to resolve the problem of autocorrelation of Si concentration between year $t$ and $t-1$.

We used similarly structures GLMM model with $\log$ link function to analyse vole density in year n. The model included: Si concentration in the leaves and rhizomes (in year $t$ ); the previous year's vole density (year $t-1$ ); the current (year $t$ ) water level as fixed effects. As with the Si models, site and year were included as a varying intercept random effect.

For all models we calculated the $\mathrm{R}$-squared values as marginal and conditional $\mathrm{R}^{2}$ statistics (according to Nakagawa et al., 2017). The marginal $\mathrm{R}^{2}$ considers only the variance of the fixed effects, while the conditional $\mathrm{R}^{2}$ takes both the fixed and random effects into account. We also provided values of part (semi-partial) $\mathrm{R}^{2}$ as the metrics of variance explained uniquely by a particular predictor.

All statistical analyses were made using packages lmerTest (Kuznetsova et al., 2017), sjPlot (Lüdecke, 2020) and partR2 (Stoffel et al.,2020) in the R software.

3 RESULTS 
Preliminary analyses revealed that $\mathrm{Si}$ concentration in sedges, vole density and ground water level varied significantly between years of study ( $\mathrm{p}<0.001$ for each of the three variables, Table 1, Figure 1$)$.

GLMM revealed that autumn $\mathrm{Si}_{\text {leaf }}$ was positively affected by the ground water level in the spring of the same year (Table 1). Same analysis also revealed the effect of the population density of voles recorded in the previous autumn (year $t-1$, Table 1, Figure 2). Although this effect did not reach statistical significance, it nevertheless explained $9.5 \%$ out of $22.6 \%$ of $\mathrm{Si}_{\text {leaf }}$ variation accounted for by all fixed factors (Table 1 ).

Concentration of $\mathrm{Si}$ in rhizomes $\left(\mathrm{Si}_{\text {rhiz }}\right)$ was significantly affected only by the ground water level in spring, whereas the effect of vole density in the same year $(t)$ and previous year $(t-1)$ was weak and not significant. All fixed effects explained $77.7 \%$ of $\mathrm{Si}_{\text {rhiz }}$ variation (Table 2). When the spring water level was removed from the model, all remaining fixed effects explained only $16.9 \%$ of $\mathrm{Si}_{\text {rhiz }}$ variation and density of voles explained alone $16.1 \%$ of $\mathrm{Si}_{\text {rhiz }}$ variation. In the resulting model the density of voles in year $t-1$ became marginally significant (GLMM, coefficient estimate $=0.12$, CI: $0.00-0.25, \mathrm{p}=0.053)$.

Neither $\mathrm{Si}_{\text {rhiz }}, \mathrm{Si}_{\text {leaf }}$ and vole density in year $t-1$ nor water level in current year, significantly affected the density of the vole population in the current year $(t)$ (Table. 3).

\section{DISCUSSION}

Our long term study revealed that (1) the amount of Si in leaves was positively related to current year water level in spring and, to a smaller extent, vole population densities from the previous year; (2) spring ground water level had a strong and positive influence on rhizome Si content, but (3) neither Si concentration in leaves or rhizomes, or water level affected the root vole population density. Thus, our findings partly corroborated the results of an earlier study by Wieczorek et al., (2015a) carried out on the same field study system. Above all, however, our results demonstrate that the plant-herbivore-water-regime nexus is more complex than has been described from laboratory (Seldal et al., 1994) and enclosure experiments (Agrell et al., 1995).

$\mathrm{Si}_{\text {leaf }}$ saw notable increases in years following especially high root vole densities $(>200$ individuals per hectare in 2008, 2014 and 2015, Fig. 1). Such a one- year- delayed plant response to grazing is in agreement with the predictions of the Plant Defence Hypothesis (Haukioja, 1980; Underwood, 1999) and suggests that, in those particular year's, herbivore densities were high enough to elicit a silification defence. Our study follows Wieczorek et al., (2015a), who similarly demonstrated that the high pressure from free-living small herbivores may elevate bio-mineralisation of tissues of grasses under natural conditions. This corroboration is important, because the findings presented in Wieczorek et al., (2015a) have been questioned by Soininen et al., (2017) on statistical grounds.

A similar mechanism of silification of grasses caused by vole grazing was observed in studies conducted both in a laboratory (Reynolds et al., 2012) and also in a landscape scale experiments (Ruffino et al., 2018). The question therefore arises of why so few confirmations of silica-induced defence mechanisms in grasses generated by the herbivorous mammals are detected in the wild, while it is so readily detected in laboratory experiments? The most intuitive explanation is that the diet of wild herbivores in natural grasslands is much more diverse than in the laboratory studies, which results in insufficient grazing pressure to induce defence mechanisms in a given plant species. Fortunately, in our study system in the Biebrza National Park, homogenous meadows consist almost exclusively of the one Carex species - the tussock sedge, constituting a primary food source of voles (Gebczyńska, 1970). Therefore, this simplest possible one plant- one vertebrate herbivore system is best suited for testing the existence of induction of silicon deposition as a defence mechanism against grazing.

The second possibility is that the elevation in Si concentration in plants is most detectable at high densities of herbivorous mammals which is easily replicated within laboratory settings (e.g. Massey \& Hartley, 2006) but difficult to capture in natural ecosystems. This may explain why the field studies conducted by Soninen et al., (2012) and Quigley et al. (2020) did not reveal consistent relationships between plant silicon concentrations and grazing. The results of our study and other two field experiments (Wieczorek et al., 2015a; Ruffino et 
al., 2018) indicate that such relationships are only detectable following response of plants to especially high herbivore densities, in this study above 200 individual/ha.

The key factor, however, complicating the analyses of the plant-herbivore interaction in our study system is the ground water level. The uptake and deposition of silicon in wetland plants is driven by hydrological and climatic factors (Struyf \& Conley, 2009; Struyf et al., 2010; Schoelynck et al., 2014), because silicic acid uptake in grasses is largely passive and determined by transpiration rate (Sangster, Hodson, \& Tubb, 2001, but see Quigley et al. 2020). Wieczorek et al., (2015a) found that ground water level positively affects $\mathrm{Si}_{\text {rhiz }}$. This result has been questioned by Soninen et al. (2017) who asserted that the effect of the ground water level in Wieczorek et al.'s, (2015a) study cannot be statistically separated from that of the vole density. Our present analysis, carried out on a much larger data set, allowing for an effective statistical control of the collinearity between independent factors, did support the existence of a strong positive effect of the ground water level on $\mathrm{Si}$ accumulation in leaves and rhizomes (Table 1 and 3 respectively). However, we found no evidence that $\mathrm{Si}_{\text {rhiz }}$ and $\mathrm{Si}_{\text {leaf }}$, in the same year, are correlated, while $\mathrm{Si}_{\text {rhiz }}$ in consecutive years was positively correlated. Thus, the dynamics of Si deposition in leaves and rhizomes follow different paths, although in both plant parts it is driven by the prevailing water regimen (Table 1 and 2).

Although high grazing pressure of voles elevated Si level in sedge's leaves in an apparent delayed densitydependent manner, it did not affect vole population densities between years. In agreement with this finding, Wieczorek et al., (2015a) found that the winter survival of voles was not associated with vole faecal $\mathrm{Si}$ concentration. In principle, this concentration should be correlated with $\mathrm{Si}_{\text {rhiz }}$, because the $\mathrm{Si}_{\text {rhiz }}$ is correlated between subsequent years of study, and thus, should also faithfully reflect winter Si concertation in rhizomes being the food base of overwintering voles. The lack of the effect of silification of sedges on the vole population dynamics was likely due to low $\mathrm{Si}_{\text {leaf }}$ and $\mathrm{Si}_{\text {rhiz }}$, which in most years of our study remained at the level of less than $1 \%$ of dry mass (Fig. 1). This level was 3-6 times lower than that reported in leaves ofDeschampsia caespitosa by Massey et al. (2008)- a study demonstrating negative effect of plant silification on the population growth and individual performance of voles (Microtus agrestis ). Likewise, Wieczorek et al.'s (2015b) study demonstrating the abrasive effect of silica on intestinal villi of voles used sedge-based diet containing $1.87 \%$ of Si in dry mass - a concentration higher than that, reported here.

\section{CONCLUSIONS}

In conclusion, our results indicate that silification process of rhizomes of sedges in our study area is mainly driven by the hydrological cycles. Si concentration in leaves appears to be dependent of the ground water level, and slightly positively affected by the previous year's vole population density. However, this effect does not create a feedback loop predicted by the Plant Defence Hypothesis, as silification of sedges was insufficient to negatively affect the root vole demography. Therefore, future research carried out on the on the Plant Defence Hypothesis should mainly focus on clarifying why and under what circumstances plants are able to accumulate silica at the levels sufficient to impinge herbivores, thereby triggering plant-herbivore interactions.

\section{ACKNOWLEDGEMENTS}

We are grateful to the Institute of Biology in Białystok for allowing us to use their Field Station in Gugny. Deon Roos provided valuable comments and linguistic correction on earlier draft of this paper. Financial support was provided by the Polish National Science Centre (grant 2011/01/B/NZ8/04259 to ZB) and the Forest Research Institute (grant 900-418 to ZB). This work complies with the cur-rent laws of Poland.

\section{AUTHORS ' CONTRIBUTIONS}

Z.B., K.Z. and M.K. conceived the ideas and designed methodology; Z.B. and K.Z. collected the data; K.Z., M.K. and Z.B. analysed the data, M.S. and M.S-M. performed chemical analyses; Z.B., M.K. and K.Z. led the writing of the manuscript. All authors contributed critically to the drafts and gave final approval for publication.

\section{COMPETING FINANCIAL INTERESTS}


The authors declare no competing financial interests.

\section{DATA AVAILABILITY STATEMENT}

Data will be available at the Dryad Digital Repository

\section{REFERENCES}

Agrell, J., Erlinge, S., Nelson, J., Nilsson, C. \& Persson, I. (1995) Delayed densitydependence in a small-rodent population. Proceedings of the Royal Society of London.

Series B, Biological Sciences , 262 , 65-70. https://doi: 10.1098/rspb.1995.0177

Andreassen, H.P., Glorvigen, P., Rémy, A. and Ims, R.A. (2013), New views on how population-intrinsic and community-extrinsic processes interact during the vole population cycles. Oikos , 122 , 507-515. https://doi:10.1111/j.1600-0706.2012.00238.x Bartoń, K. (2013) MuMIn: multi-model inference. R package version.

Batzli, G.O. \& Henttonen, H. (1990) Demography and resource use by microtine rodents near Toolik Lake, Alaska, U.S.A. Arctic and Alpine Research , 22 , 51- 64. https://doi: 10.1080/00040851.1990.12002765

Borowski, Z. (2002) Individual and seasonal differences in antipredatory behaviour of root voles - a field experiment. Canadian Journal of Zoology ,80 , 1520-1525. https://doi:

$10.1139 / z 02-154$

Borowski, Z. (2011) The impact of predation on small rodent population dynamics as exemplified by the root vole (Microtus oeconomus ). Papers of the Forest Research Institute, Dissertation \& Monographs, 15, pp. 124 [in Polish]. Brightly, W.H., Hartley, S.E., Osborne, C.P., Simpson, K.J., Strömberg, C.A.E. (2020) High silicon concentrations in grasses are linked to environmental conditions and not associated with C4 photosynthesis. Glob Change Biol. 26 : 7128- 7143.

https://doi.org/10.1111/gcb.15343

Burnham, K.P. \& Anderson, D.R. (1998) Model selection and inference: A practical information-theoretic approach. New York, NY: Springer. https://doi:

10.1007/978-1-4757-2917-7

Calandra, I., Zub, K., Szafrańska, P., Zalewski, A. \& Merceron, G. (2016) Silicon-based plant defences, tooth wear and voles. Journal of Experimental Biology ,219 , 501- 507.

https://doi: 10.1242/jeb.134890

Faisal, S., Callis, K.L., Slot, M. \& Kitajima, K. (2012) Transpiration- dependent passive silica accumulation in cucumber (Cucumis sativus) under varying soil silicon availability.

Botany-Botanique, 90 , 1058-1064. https://doi: 10.1139/b2012-072

Gebczyńska, Z. (1970) Bioenergetics of a root vole population. Acta Theriologica, 
15, 33- 66. https://doi: 10.2307/3543589

Haukioja E. (1980) On the role of plant defenses in the fluctuation of herbivore

populations. Oikos . 35 , 202-213. https://doi: 10.2307/3544428

Kindomihou, V., Sinsin, B. \& Meerts, P. (2006) Effect of defoliation on silica accumulation

in five tropical fodder grass species in Benin. Belgian Journal of Botany, 139, 87-102.

https://doi: 10.2307/20794597

Klemola, T., Koivula, M., Korpimäki, E. \& Norrdahl, K. (2000) Experimental tests of

predation and food hypotheses for population cycles of voles.

Proc. R. Soc. Lond.

B . 267 :351-356. http://doi.org/10.1098/rspb.2000.1008

Kuznetsova A., Brockhoff P.B., Christensen R.H.B. (2017) LmerTest Package: Tests in Linear Mixed Effects Models. Journal of Statistical Software, 82, 1-26.

Lambin, X., Petty, S.J. \& Mackinnon, J.L. (2000), Cyclic dynamics in field vole populations and generalist predation. Journal of Animal Ecology , 69 : 106-119. https://doi.org/10.1046/j.1365-2656.2000.00380.x

Lüdecke D. (2020) sjPlot: Data Visualization for Statistics in Social Science. R package version 2.8.5, https://CRAN.R-project.org/package=sjPlot.

Massey, F.P. \& Hartley, S.E. (2006) Experimental demonstration of the antiherbivore effects

of silica in grasses: impacts on foliage digestibility and vole growth rates. Proceedings

of the Royal Society of London. Series B, Biological Sciences , 273 , 2299-2304.

https://doi: 10.1098/rspb.2006.3586

Matuszkiewicz, W. (2020) Guide to the identification of plant communities in Poland. $3^{\text {rd }}$

Edition, PWN, Warsaw [In Polish].

Nakagawa S., Johnson P., Schielzeth H. (2017) The coefficient of determination $\mathrm{R}^{2}$ and intra-class correlation coefficient from generalized linear mixed-effects models revisited and expanded. Journal of the Royal Society Interface 14 . https://doi: 10.1098/rsif.2017.0213

Oli, M.K. (2019), Population cycles in voles and lemmings: state of the science and future

directions. Mammal Review , 49 , 226-239. https://doi:10.1111/mam.12156

Quigley, K.M. \& Anderson, T.M. (2014) Leaf silica concentration in Serengeti grasses

increases with watering but not clipping: insights from a common garden study and

literature review. Functional Plant Ecology , 5 , 568.

https://doi:10.3389/fpls.2014.00568

Quigley, K. M., Griffith, D. M., Donati, G. L., and Anderson, T. M.. 2020. Soil nutrients and precipitation are major drivers of global patterns of grass leaf silicification. Ecology,

101 (6): https://e03006. 10.1002/ecy.3006

Raven, J.A. (1983) The transport and function of Si in plants.Biological Reviews , 58 , 179-

207. https://doi: 10.1111/j.1469-185X.1983.tb00385.x 
Reynolds, J.J.H., Lambin, X., Massey, F.P., Reidinger, S., Sherratt, J.A., Smith, M.J. et al. (2012) Delayed induced silica defences in grasses and their potential for destabilizing herbivore population dynamics. Oecologia , 170 , 445- 456.

https://doi: 10.1007/s00442-012-2326-8

Ruffino, L., Hartley, S.E., DeGabriel, J.L. \& Lambin, X. (2018) Population-level

manipulations of field vole densities induce subsequent changes in plant quality but no impacts on vole demography. Ecology and Evolution , 8, 7752- 7762.

https://doi:10.1002/ece3.4204

Sangster, A.G., Hodson, M.J. \& Tubb, H.J. (2001) Silicon deposition in higher plants. Silicon in Agriculture (eds. L.E. Datonoff, G.H. Snyder \& G.H. Korndorfer), pp 85- 114.

Elsevier Science, New York.

Schoelynck, J., Muller, F., Vandevenne, F., Bal, K., Barao, L., Smis, A. et al. (2014) Siliconvegetation interaction in multiple ecosystems: a review. Journal of Vegetation Science,

25 , 301- 313. https:// doi: 10.1111/jvs. 12055

Seldal, T., Andersen, K., \& Hogstedt, G. (1994). Grazing-Induced Proteinase Inhibitors: A Possible Cause for Lemming Population Cycles. Oikos ,70 (1), 3-11.

https://doi:10.2307/3545692

Soininen, E.M., Brathen, K.A., Herranz Jusdado, J.G., Reidinger, S. \& Hartley, S.E. (2013)

More than herbivory: levels of silicon-based defences in grasses vary with plant

species, genotype and location. Oikos, $\mathbf{1 2 2}, 30-41$.

https://doi: 10.1111/j.1600-0706.2012.20689.x

Soininen, E. M., Hamel, S., \& Yoccoz, N. G. (2017). Importance of study design and robust analyses in ecology - what is the evidence for silica-vole interactions? Functional

Ecology , 31 (9), 1847- 1852. https://doi: 10.1111/1365-2435.12830

Stoffel, M.A., Nakagawa, S., Schielzeth, H. (2020). partR2: Partitioning R2 in generalized linear mixed models. bioRxiv 2020.07.26.221168; doi: https://doi.org/10.1101/2020.07.26.221168

Struyf, E. \& Conley, D.J. (2009) Silica: an essential nutrient in wetland biogeochemistry.

Frontiers in Ecology and the Environment , 7 , 88- 94. https://doi: 10.1890/070126

Struyf, E., Morth, C.-M., Humborg, C. \& Conley, D.J. (2010) An enormous amorphous silica stock in boreal wetlands. Journal of Geophysical Research ,115, G04008.

https://doi: 10.1029/2010JG001324

Tast, J. (1966) The root vole, Microtus oeconomus (Pallas), as an inhabitant of seasonally

flooded land. Annales Zoologici Fennici, 3, 127- 171. https://doi: 10.2307/23731273

Underwood, N. (1999) The influence of plant and herbivore characteristics on the interaction between induced resistance and herbivore population dynamics. The American 
Naturalist, 153, 282- 294. https://doi: 10.1086/303174

Wieczorek, M., Zub, K., Szafrańska, P.A., Ksiażek, A. \& Konarzewski, M. (2015a) Plant-

herbivore interactions: silicon concentration in tussock sedges and population

dynamics of root voles. Functional Ecology, 29, 187- 194. https:// doi: 10.1111/1365-2435.12327

Wieczorek, M., Szafranska, P.A., Labecka, A.M., Lazaro, J. \& Konarzewski, M. (2015b)

Effect of the abrasive properties of sedges on the intestinal absorptive surface and

resting metabolic rate of root voles. Journal of Experimental Biology , 218, 309-315.

https://doi: 10.1242/jeb.117168

Zub, K., Borowski, Z., Wieczorek, M., Szafrańska, P.A. \& Konarzewski, M. (2014) Lower

body mass, but higher metabolic rates enhance winter survival in the root voles,

Microtus oeconomus. The Biological Journal of the Linnean Society, 113 , 297-309.

https://doi: 10.1111/bij.12306

\section{Hosted file}

image1.wmf available at https://authorea.com/users/430332/articles/533839-plant-herbivoreinteractions-combined-effect-of-ground-water-level-root-vole-grazing-and-sedgesilication

\section{Hosted file}

image2.wmf available at https://authorea.com/users/430332/articles/533839-plant-herbivoreinteractions-combined-effect-of-ground-water-level-root-vole-grazing-and-sedgesilication

\section{Hosted file}

image3.wmf available at https://authorea.com/users/430332/articles/533839-plant-herbivoreinteractions-combined-effect-of-ground-water-level-root-vole-grazing-and-sedgesilication

\section{Hosted file}

image4.wmf available at https://authorea.com/users/430332/articles/533839-plant-herbivoreinteractions-combined-effect-of-ground-water-level-root-vole-grazing-and-sedgesilication

Figure 1. (a) Level of the ground water (mean +/- SE), concentration of Si (mean +/- SE) in leaves (b) and rhizomes (c) ofCarex appropinquata (d) autumn density of Microtus oeconomus, at Gugny site (solid line) and Barwik site (dashed line).

\section{Hosted file}

image5.wmf available at https://authorea.com/users/430332/articles/533839-plant-herbivoreinteractions-combined-effect-of-ground-water-level-root-vole-grazing-and-sedgesilication

Figure 2 The association between previous year vole density (n-1) and the current year concentration of $\mathrm{Si}$ in leaves $\left(\mathrm{Si}_{\text {leaf }}\right)$. 
Table 1 Estimates of averaged model parameters with confidence intervals for the effect of water level in spring in year $t$, Si concentration in rhizomes in year $t$, and vole density in yeart -1 and year $t$, on the autumn concentration of $\mathrm{Si}$ in leaves.

\begin{tabular}{lllll}
\hline Predictors & Estimates & $C I$ & $p$ & part $R^{2}$ \\
\hline (Intercept) & 0.75 & $0.56-0.93$ & $<\mathbf{0 . 0 0 1}$ & \\
Vole density year $t-1$ & 0.04 & $0.00-0.09$ & $\mathbf{0 . 0 5 6}$ & $\mathbf{0 . 0 9 5}$ \\
Vole density year $\mathrm{t}$ & 0.03 & $-0.02-0.09$ & 0.224 & 0.030 \\
$\mathrm{Si}_{\text {rhiz }}$ & -0.07 & $-0.16-0.01$ & 0.096 & 0.027 \\
Water level in spring & 0.47 & $0.13-0.80$ & $\mathbf{0 . 0 0 6}$ & $\mathbf{0 . 1 3 3}$ \\
Marginal $\mathrm{R}^{2}$ & 0.226 & & & \\
Conditional $\mathrm{R}^{2}$ & 0.287 & & & \\
\hline
\end{tabular}

Table 2 Estimates of averaged model parameters with confidence intervals for the effect of water level in spring in year $t$, Si concentration in leaves in year $t$, and vole density in yeart -1 and year $t$, on the autumn concentration of $\mathrm{Si}$ in rhizomes.

\begin{tabular}{lllll}
\hline Predictors & Estimates & $C I$ & $p$ & part $R^{2}$ \\
\hline (Intercept) & 0.70 & $0.29-1.12$ & $\mathbf{0 . 0 0 1}$ & \\
Vole density year $t-1$ & 0.03 & $-0.06-0.13$ & 0.484 & 0.011 \\
Vole density year $t$ & 0.06 & $-0.04-0.15$ & 0.230 & 0.029 \\
$\mathrm{Si}_{\text {leaf }}$ & 0.01 & $-0.18-0.20$ & 0.900 & 0.000 \\
Water level in spring & 1.46 & $0.83-2.10$ & $<\mathbf{0 . 0 0 1}$ & 0.609 \\
Marginal R $^{2}$ & 0.777 & & & \\
${\text { Conditional } \mathrm{R}^{2}}^{0.909}$ & & & \\
\hline
\end{tabular}

Table 3 Estimates of averaged model parameters with confidence intervals for the effect of water level in spring in year $t$, Si concentration in leaves and rhizomes in year $t$, and vole density in year $t-1$ and year $t$ , on the autumn density of voles in year $t$.

\begin{tabular}{lllll}
\hline Predictors & Estimates & $C I$ & $p$ & part $R^{2}$ \\
\hline (Intercept) & -0.40 & $-0.95-0.16$ & 0.161 & \\
Vole density year $t-1$ & -0.20 & $-0.44-0.03$ & 0.094 & 0.268 \\
$\mathrm{Si}_{\text {rhiz }}$ & 0.10 & $-0.19-0.39$ & 0.506 & 0.059 \\
$\mathrm{Si}_{\text {leaf }}$ & 0.06 & $-0.19-0.30$ & 0.637 & 0.001 \\
Water level in spring & -0.05 & $-0.91-0.81$ & 0.903 & 0.000 \\
Marginal R & & & & \\
Conditional $\mathrm{R}^{2}$ & 0.269 & & & \\
\hline
\end{tabular}

